\title{
Between a Rock and a Hard Place: Constitutional Conflict Cases before The Romanian Constitutional Court
}

\author{
Csongor Kuti*
}

\begin{abstract}
For the rule of law-based democratic regimes, at least two types of significant political challenges can be identified:

1. Challenges coming from outside of the democratic regime, in the form of movements which, by making use of the constitutionally guaranteed rights and liberties, attempt to destroy the democratic establishment.

2. Challenges coming from inside the democratic regime, in the form of authoritarian movements, which are attempting to overcome their political opponents and consolidate their power by the misuse of the institutions found under their control according to the constitutional blueprint.

This paper is concerned with the second type of challenges and examines how the power struggle reflects in constitutional adjudication. Focusing on the case law of the Romanian Constitutional Court, it analyzes the trends in the evolution of the Court's interpretation of constitutional conflict issues. The paper argues that in periods of great political fragmentation and power-struggle, constitutional conflict cases are more present in the Court's docket and they result in much more disputed decisions, as actors attempt to present political conflicts as judicial ones. The Court itself is getting more drawn into these struggles and gradually loses its 'independent arbitrator' stance.
\end{abstract}

Keywords: Romanian Constitutional Court, constitutional conflicts, constitutional interpretation

Constitutional adjudication does not have a particularly rich history in Romania. It was only the 1991 Constitution that provided a Constitutional Court as a specialized forum to hear claims of unconstitutionality. The first Romanian constitution dates back to 1866 but there was no constitutional or judicial review until 1912, when a landmark decision of the Ilfov Tribunal carved out judicial review powers for ordinary courts. The dominant view in legal theory rejected the judges' ability to declare a law unconstitutional. Arguments drew on the concept of symmetry, according to which no final decision of a court can be annulled upon considerations of illegality and the idea of hermetic separation of powers, i.e. each power is sovereign within its own sphere of competence. Judicial review was later legitimized by the 1923 Constitution and was part of the constitutional design until the communist takeover. However, it did not produce a relevant case-law. ${ }^{1}$

The idea of constitutional adjudication was not remarkably popular at the drafting of the first democratic constitution either. Politicians and the judiciary both feared a countermajoritarian undemocratic body that could encroach upon their powers. ${ }^{2}$ This might explain why, at the outset, the Court was not designed as a true final arbiter. Its priori review rulings could have been overruled by a qualified majority vote in the parliament and it lacked the competence to decide constitutional conflict issues. ${ }^{3}$

Consequently, for about a decade, the Court, and the logic of constitutionalism, remained in the background of political transition, being heavily criticized by legal

\footnotetext{
* University of Arts Târgu Mureş, kcsongi@yahoo.com.

1 Benke (2019).

2 Mungiu-Pippidi (1997) 78-83.

3 Kuti (2019) 155-83.
} 
scholarship for its 'irrelevance' and 'ignorance.' ${ }^{4}$ From an instrumentalist perspective, the Court's rather discrete stance, its constant concern not to become a positive legislator, at least in comparison with some of its Central and East European counterparts, has been praised by others, who considered the 1991 Constitution as the real 'engine of transition', which only needed to be enforced by the Court, without any creative activism. ${ }^{5}$

The constitutional design and inevitably the Court's role has been significantly amended in 2003, arguably with a view to the forthcoming EU accession. Separation of powers has been expressly provided for in the constitutional text, parliaments' possibility to override a priori review decisions has been eliminated, and the Court has been granted the power to adjudicate cases of constitutional conflict. These, along with several other adjustments, contributed towards the strengthening of the Court's review powers and produced noticeable shifts in its attitude. Its visibility increased, public debates gained constitutional dimensions and the Court found itself amidst embittered political battles. ${ }^{6}$

From the outset, the Court was designed to consist of 9 judges, appointed for a nonrenewable mandate of 9 years, except for the first Court, which was appointed to allow for the renewal of one-third of the mandates every 3 years. Although, in practice, there were situations in which judges appointed for a fraction of a mandate, were subsequently confirmed for a full mandate of 9 years. The judges are appointed, three each, by the two chambers of the parliament and the president of the republic. After entering into office, they elect, from amongst themselves, a president of the court, for a renewable mandate of 3 years. The Court adopts its decisions sitting as a full court, by a majority of the judges. The votes of the judges are not made public, the texts of the decisions contain merely the names of the attending judges and usually mention if the decision has been taken by a majority vote, unfortunately, this practice, as well as the editing of the decisions' texts is not entirely consistent throughout the years. Dissenting and concurring opinions are usually published together with the decision. However, since 2017, the president of the Court has the power to request a rephrasing of such opinions, and may ban their publishing, if not in line with the Courts' own strict rules of editing. ${ }^{7}$ In this case, the opinions will not be attached to the case file. This procedure has been criticized by the Venice Commission as problematic and to be avoided. ${ }^{8}$ A telling example is the political battles through which the Court is forced to navigate. The administrative act, referring to the rules of editing of opinions, has been annulled in first instance by the Bucharest Court of Appeal in 2018, but the case is still pending (on appeal) before the High Court of Cassation and Justice.

The Romanian political landscape is a semi-presidential republic, with a directly elected president, who possesses several foreign policy competences, appoints various public officials, presides the Supreme Council of National Defense and may attend (and in these cases also preside) meetings of the executive and also attend the Superior Council of Magistracy (the governing body of the judiciary).

${ }^{4}$ Weber (2002) 283-308.

5 Tănăsescu (2013) 19-36.

${ }^{6}$ Iancu, Bogdan (2009) 187-211.

7 Decision no. 1/22.06.2017 'prohibits assessments of a sententious, ostentatious, provoking nature or politically suggestive opinions, as well as those leading to such an end point.' Moreover, 'separate and concurrent opinion cannot transgress the point of view of the judge so as to become a direct criticism of the decision of the Constitutional Court and it cannot become a party examination or an open criticism to the decision of the Constitutional Court'.

8 European Commission for Democracy Through Law, Opinion no.932/2018. 
The political class is rather fragmented and fluid. No single party since the 1992 elections has managed to obtain a majority in parliament and no coalition has enjoyed a stable 2/3 majority. Moreover, in the new millennium, no coalition managed to resist the full parliamentary cycle. Since the presidential elections of 2004, the party who sustained the winning candidate, often found itself in opposition. This in turn led to continuous tensions between the president and the executive, one president even survived two suspensions from office procedures (Basescu, in 2007 and 2012). The last decade proved to be highly unstable, even by Romanian standards; 8 different prime ministers have been appointed since the 2008 elections and none has fulfilled a complete 4 year term.

\section{CONSTITUTIONAL CONFLICTS}

The 2003 revision of the Romanian Constitution expanded the Court's review powers to 'juridical conflicts of constitutional nature' but neither the constitutional norm nor the Law on the organizing and functioning of the Constitutional Court ${ }^{9}$ provides any explanations about the content of these conflicts. According to the fundamental law, the Court is entitled to adjudicate juridical conflicts of constitutional nature between public authorities, at the request of the President of the Republic, either of the presidents of the two chambers of Parliament, the Prime Minister or the President of the Superior Council of Magistracy. ${ }^{10}$ Interestingly, in the decision on the mandatory constitutional review of the revision bill, the Court noted that this provision should be interpreted as referring to conflicts of authority (as opposed to political conflicts) and for avoiding the involvement of the Court in political conflicts, it should be expressly introduced in the constitutional text that such conflicts represent 'institutional deadlocks', i.e. positive or negative conflicts of competence. ${ }^{11}$ This view has been echoed also by constitutional scholars, who emphasized the importance of isolating the Court from political conflicts. ${ }^{12}$

The Court remained faithful to its initial take on the issue, and in the absence of constitutional or legal provisions, it elaborated on its own constitutional conflicts theory through its decisions. In its very first constitutional conflict decision, the Court stressed that opinions, value judgements or statements of a high official referring to other public authorities do not generate by themselves constitutional conflicts as they should be considered as political speech, protected by the freedom of expression clause of the Constitution. ${ }^{13}$

In the same decision, the Court also argued that constitutional conflicts must take the form of concrete acts of actions by which an authority arrogates powers, attributions or competences that, according to constitutional provisions, belong to other authorities or refuses to fulfill acts that belong to its area of competence.

Later decisions further refined the Court's take on constitutional conflicts. It was (re)stated that constitutional conflicts must led to 'institutional deadlocks' ${ }^{14}$ that, as a

9 Law no.47/1992.

10 Constitution of Romania, art. 146, point e).

11 Decision no. 148/2003.

12 Deleanu (2006) 865.

13 Decision no. 53/2005.

14 Decision no. 97/2008. 
slight departure from the initial approach, the Court may adjudicate on any juridical conflicts, which was directly generated from the constitutional text $\mathrm{t}^{15}$ and that only certain authorities may be parts of such a conflict. ${ }^{16}$ The Court also emphasized, that political parties or factions of the parliament do not have standing in constitutional conflict cases. ${ }^{17}$

The Court stated from the outset i.e., the early admission decisions, that whenever the existence of an 'institutional deadlock' is established, it must act to remove such deadlocks. The Court derived its obligation from the rule of law provision of the Constitution ${ }^{18}$ arguing that one of the conditions for the fulfilling of the state's fundamental objectives (the rule of law, democracy, individual dignity, rights and liberties etc.) is the good functioning of public authorities, respecting the principle of separation of powers, without institutional deadlocks'. ${ }^{19}$

However, identifying a constitutional reason (legitimation) for the obligation of removing 'institutional deadlocks' was only part of the problem. The Court still has to work out the grounds for concretely resolving such situations. The constitutional legitimation was found in the article upon the structure of the constitutional court, whereas the first paragraph states that the Court is the guarantee for the supremacy of the Constitution. ${ }^{20}$ Based on this provision, the Court argued that, as guarantor of the Constitution's supremacy, it must resolve constitutional conflict cases by indicating the constitutional conduct that public authorities must conform to. ${ }^{21}$

Pointing to constitutional provisions as grounds upon which the Court understood to exercise its power did not by itself make the Court's life easier, because in these cases it has to hand out solutions that are very different from those formulated in its 'common', constitutional review jurisdiction. In constitutional (a posteriori) review cases, even if the claims are generated from concrete juridical conflicts before the regular courts, the constitutional review by itself does not offer a concrete remedy for the conflict that triggered the review procedure. The Court does not give a solution, it only examines if the norm in question is in conformity or not with the constitutional blueprint, leaving it up to the regular courts to 'do justice', to decide upon the case. In the constitutional conflict cases, the Court itself identified a constitutional obligation to come up with a solution. Unfortunately, this solution must also be in line with another constitutional provision pertaining to the organization and functioning of the constitutional court. Namely, the fundamental law establishes that the decisions of the constitutional court may produce effects only for the future. $^{22}$ Therefore, in the early constitutional conflict cases, the Court found that its' decisions may only regard those acts, actions or inactions of the public authorities involved, that will occur in the future. ${ }^{23}$

15 Decision no. 270/2008.

16 Decision no. 901/2009.

17 Decision no. 53/2005, supra, note 6.

18 Constitution of Romania, art. 1 para. 3.

19 Decision no. 98/2008.

20 Constitution of Romania, art. 143 para. 1.

${ }^{21}$ Decision no. 838/2009.

22 Constitution of Romania, art. 147 para. 4.

23 Decision no. 838/2009, supra, note 14 . 


\section{RESEARCH}

This research investigates how the approach of the Romanian Constitutional Court to the issue of constitutional conflicts has evolved from initial principles and argues that these evolutions can be linked to the political context in which they take place.

Therefore, without attempting to turn into a political science analysis, this paper identifies and examines indicators that could be considered relevant for the shift in the Court's case-law.

From a quantitative perspective, the research examines the evolution in the number of constitutional conflict claims, their admission rates, the number of dissenting opinions generated, the structure of the claims and the componence of the Court (formal political affiliation and networks of judges). Whereas from a qualitative perspective, the evolutions in the remedies offered by the Court, in the admission decisions, are taken under investigation.

The research covers the period between 2003 and 2019, extending from the year of the constitutional revision that introduced the review power of the Court over constitutional conflict cases, to the last full year before the publication of the present research. This period comprises a total of 38 decisions, spread over 13 years. There were four years, in which no such claims have been filed.

Data is examined in the light of the general figures of the Court's case law (which made the object of a different research project ${ }^{24}$ ), and in the light of the political context, which is determined on the basis of indicators such as the componence of the Parliament, the governing parties or coalitions, the formal political affiliation of the President of the Republic.

\subsection{Numbers}

The Romanian Constitutional Court has an incredible workload, having issued 20,149 decisions from the beginning of its existence to the end of 2019. This means, on the average, 720 decisions pro year and it is difficult to find an epithet for such numbers.

Most of these decisions were issued in a posteriori review proceedings with a small fraction being represented by a priori review proceedings. The remaining decisions are made up by reviews of the rules and regulations of Parliament and, finally, by juridical conflicts of constitutional nature: 38 decisions altogether.

Constitutional conflict decisions have an admission rate of $50 \%$, which is somewhat lower than the admission rate of a priori review decisions (52,17\%), and incomparably higher than the admission rate of a posteriori review decisions $(2,27 \%)$ for the same period (2003-2019). This distortion between the success rates may hint towards the idea that the Court is more concerned with solving problems of constitutionality arising out of political conflicts than claims arising out of ordinary litigation. At least, political actors tend to use $a$ priori and constitutional conflict review claims as means of political dispute. ${ }^{25}$

At the discussion of admission rates, it is also worth observing the differences in outcome between the constitutional conflict claims filed by the various actors. It appears

24 Judicial Constraints on Legislation in Central Europe (2020) link 1. For a detailed analysis of Romania see: Kuti, 2019.

25 Perju (2010). 
that claims filed on behalf of the judicial power (by the Superior Council of Magistracy), enjoy the lowest degree of success rate whilst claims coming from the executive are most likely to result in an admission decision (fig.1).

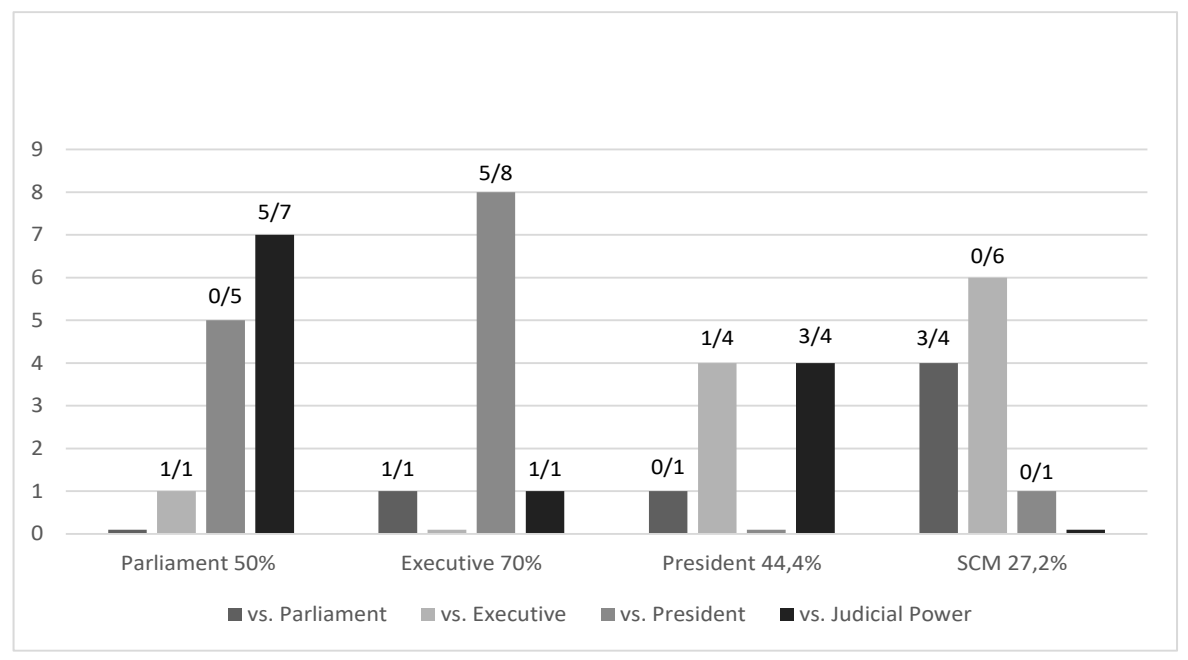

Figure 1. Complaints filed and admission rates

According to the numbers, the executive appears to have the upper hand over the other actors, enjoying a higher-than-the-average degree of admission rate, accompanied by a $16-5$ for-against rulings ${ }^{26}$ record, which means that out of 21 constitutional conflict rulings in which it has been involved, in 16 cases the Court issued a solution favorable for the executive, as compared to a 4-18 records for the judicial power. These are quite interesting that the judicial power is a counter-majoritarian, professional body while the other two (parliament and the president) are the only directly elected. It is also noticeable that collisions of competence occur most frequently between the legislative and the judicial power, or the executive and the president of the republic. The latter is largely due to the semi-presidential structure of the government, and conflicts are often generated by disputes over the appointment and discharging of public officials. With due caution, keeping in mind that this is about a relatively short period of time and a relatively low number of cases, it can be argued that there is a shifting trend in the Court's attitude towards solving constitutional conflicts between the executive and the president of the republic. Namely, on the basis of its newer (2018-2019) decisions, the Court is apparently tilting the balance of power between the two actors towards the executive i.e., the governing party/coalition, showing arguable traces of a shift from a semi-presidential towards a parliamentary system. Since the introduction of the collision of competence jurisdiction and up until the end of

26 'Rulings', as a unit of analysis are used here, as they offer a clearer picture. Decisions sometimes address more than one issue, and may offer different solutions to them. In the general case-law of the Court, as well as in constitutional conflict cases, the number of rulings exceeds the number of decisions with a narrow margin. 
2019, there were altogether 11 decisions addressing conflicts that arose between the executive and the president of the republic. The majority of them occurred in 2014 (4 decisions) and 2018-2019 (again, 4 decisions). From the perspective of the political context, there is a high degree of similarity. Both periods are characterized by embittered conflicts between the two institutions, both ending with the adoption of a motion of no confidence and the consequent dismissal of the executive, and both included presidential elections (November 2014 and November 2019). Still, the outcome of the Constitutional Court decisions in these cases are markedly different. In 2014, all claims lodged by the two actors - one by the president of the republic and three by the prime-minister - were rejected. However, in 2018-2019, only the claim lodged by the president were rejected, while all three claims of the prime-minister were admitted. Moreover, these admission decisions offer extra strong remedies worded in an unusually imperative language: 'The President shall issue the decree...' (Decision no. 358/2018); 'The President shall immediately issue the decrees [...] The President shall immediately offer a written and justified answer...' (Decisions no. 875/2018 and 504/2019). The issue of the equilibrium between the powers of the executive and of the president of the republic and the proper definition of the Romanian system of government has been a constant concern for the judges of the Court. In a 2012 common dissenting opinion, a coalition of four judges expressed their fears regarding the transformation of the republic into a presidential system. They argued that the Romanian political system could be defined as a 'rationalized parliamentary regime', characterized by emphasis on the avoidance of institutional conflicts and ensuring of a parliamentary majority in the support of the executive, limiting 'the play' of the main elements of parliamentarism so as to avoid 'a drifting' of the system and governmental instability. ${ }^{27}$ It must be noted that all four dissenters were 'politician-judges' (former MP's), a category which represented the majority in the Court until 2016. Another relevant data is represented by the number of dissenting opinions. As the voting behavior of the judges is not made public (the text of the decision merely indicates the participating judges), the only possibility to identify a judge's position towards a decision is offered by the concurring and dissenting opinions. The decisions often also mention whether they were taken by unanimity or by a majority vote, however, this practice has not been consistent, the texts sometimes remain silent upon this issue. Therefore, in order to deal with this inconsistency, the research presumes that if a decisions' text does not mention a majority vote (and it is not accompanied by dissenting opinions), it should be considered as a unanimous decision.

Accordingly, the pattern of decisions indicates that constitutional conflict cases are likely to be decided by a majority opinion, which is quite reasonable, if their political relevance is taken into consideration. It is only the last three years of the analyzed period, in which majority decisions became increasingly dominant and it must be noted that this period was also marked by increasing political tension and instability. (fig.2)

The dataset contains four decisions that were certainly taken with the narrowest possible majority, i.e. all minority judges formulated dissenting opinions, an impressive percentage, when compared to the whole caseload of the Court $(10.5 \% \mathrm{v}$. less than $0.1 \%)$.

${ }^{27}$ Common dissenting opinion of judges Puskás, Gașpar, Predescu and Toader, Decision no. $784 / 2012$. 


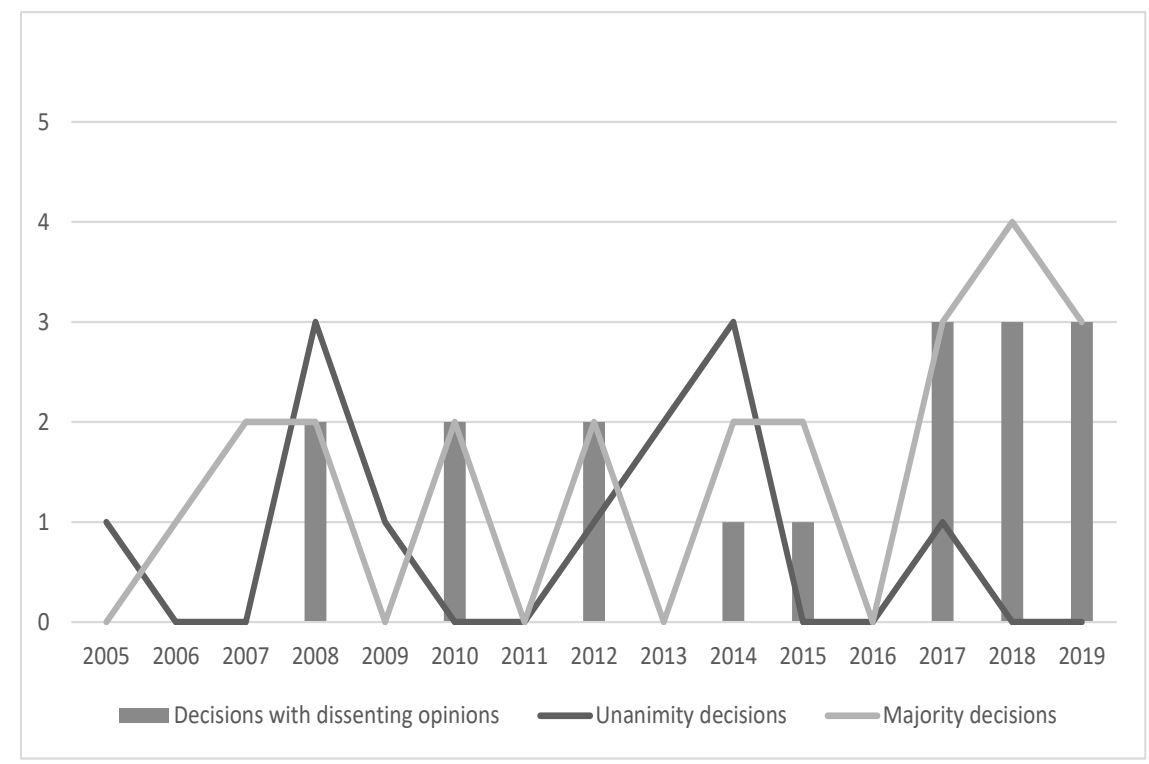

\section{Figure 2. Pattern of decisions}

Further, if admission and rejection rulings are analyzed separately, it results in admission rulings being considerably more disputed than rejection rulings: only one third are unanimity, while judges could reach an agreement in more than half of the rejection rulings. The difference is even larger if dissenting opinions are taken into consideration as admission rulings generated almost five times more dissenting opinions than rejections, meaning that the disagreement between the judges must have been stronger. (fig. 3 )

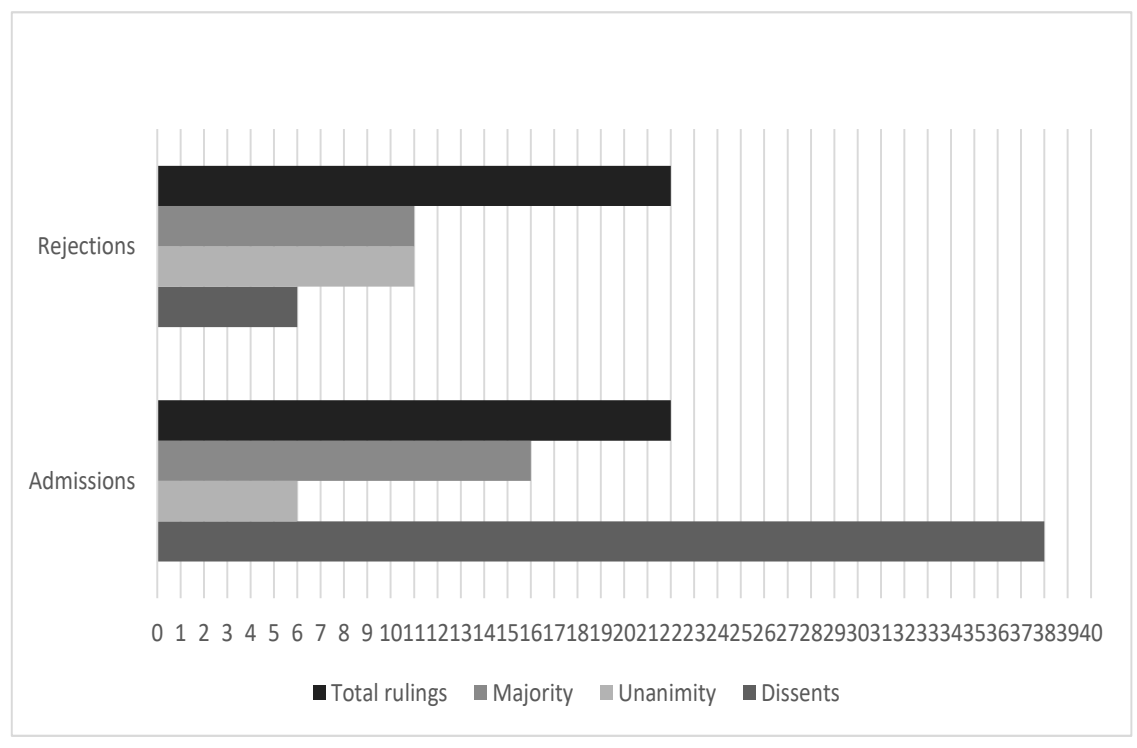

Figure 3. Constitutional conflict rulings 
Finally, the last quantifiable factor that can be taken into consideration is the formal political affiliation of constitutional judges. Judges of the Court are appointed by political actors and, even if there is a requirement that judges must be experienced legal professionals, it became customary to appoint also members of the parliament as justices. Up to 2016, former MPs constituted the majority of the Court. Another custom, which was observed during the first 15 years of the court, demanded that the party or coalition that nominated a judge whose mandate expired, should also nominate the new judge. Obviously, being a former MP is neither the single, nor an absolute ${ }^{28}$ indicator of a judges' ideological preference, however, arguably it is the most objective one available. Interestingly, while an analysis on the general case-law of the Court, in spite contrary claims by scholars, could not demonstrate a link between former political affiliation of judges and their (dissenting) voting behavior. ${ }^{29}$ However, narrowing the scope to politically highly sensitive issues such as constitutional conflict cases leads to a markedly different result. Accordingly, in the analyzed period judges tended to form dissenting 'coalitions' 30 according to their formal political affiliation, with the single ideologically and practically centrist judge ${ }^{31}$ representing the bridge between the two sides of the political spectrum. During the period when the Court was dominated by politician-judges, all dissenting opinions published in constitutional conflict cases reflect partisan dissenting behavior: i.e. politician-judges dissents' were, without a single exception, in line with their former parties' interests in the given case. ${ }^{32}$ It is very interesting to note, without forgetting the uncertainty induced by the shortness of the timeframe and the low number of relevant decisions, that the relative ${ }^{33}$ 'professionalization' of the Court, noticeable especially since 2016, when 'politician-judges'

${ }^{28}$ For instance, a judge appointed by the liberal party (PNL), has later become Minister of justice in a social-democrat (PSD) executive. In fairness it also has to be noted that political fidelity is highly fluid on the Romanian scene, MP's shifting from one party to another with ease, and not necessarily on ideological grounds.

${ }^{29}$ Kuti (2019) 155-83.

${ }^{30} \mathrm{By}$ 'coalition' I understand the situation in which two or more judges formulate a dissenting opinion against the same ruling, regardless whether they share the same reasons or not.

31 The Hungarian minority alliance (UDMR) traditionally gets to nominate one judge to the Court, while holding only approximately $6 \%$ of the seats in the Parliament. As a political actor, it necessarily assumes a centrist stance, and attempts to position itself as decisive factor between the opposition and the government, in order to maximize its possibilities.

32 For example: Decision no.98/2008 found a constitutional conflict between the President (elected on behalf of the PD party) and the Executive (supported by the PNL and UDMR parties' coalition) and ruled in favor of the President. Former PNL and UDMR MP's, justices Toader and Puskás signed a common dissent arguing that the remedies should have been awarded in favor of the Executive. Decision no. 1525/2010 admitted the Executive's (supported by PD-L) claim against the Parliament's (dominated by PSD). Former PSD MP's, justices Gaspar and Cojocaru signed a common dissent together with former PNL MP, justice Toader. Decision no. 683/2012 admitted the President's (elected on behalf of the PD) claim against the Executive (supported by PSD and PNL). Former MP's, judges Gaspar, Cojocaru (both PSD) and Toader (PNL) submitted a joint dissent. There are 8 decisions in the given period, each conforming to the above-presented pattern.

33 While career magistrates have presumably weaker ties with political actors than former MP's, some of the legal professionals appointed to the Romanian Constitutonal Court have had prior political or administrative experience as minister of justice, state secretary in the ministry of justice or counselor in the presidential administration. Positions that presume not only professional expertise, but also a degree of political reliability. 
were first time outnumbered by career magistrates, did not result in a lesser degree of polarization $^{34}$ in cases of constitutional conflict decisions. Thus, judges without formal political affiliation did not form dissenting 'coalitions' with left-wing judges; at best they rallied either the right-wing or centrist judges. Since 2019, there are only three former politician-judges left, two from the social-democrat party and one from the Hungarian minority party, and at this stage it is difficult to accurately establish whether careermagistrates might form a third pole within the Court. (fig.4)

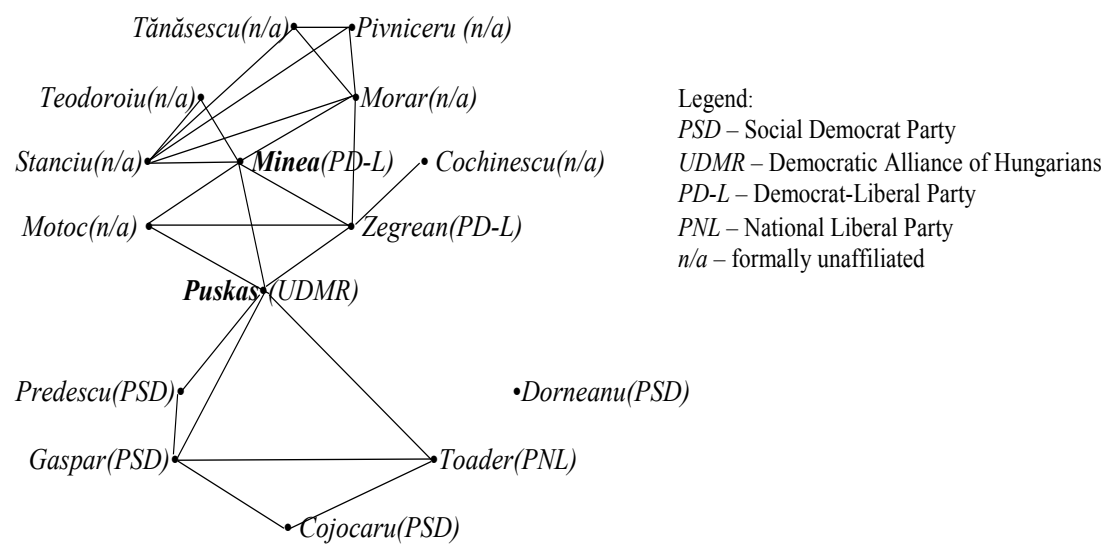

Figure 4. Network of dissenting coalitions

An analysis of dissenting opinions and partisanship in the case-law of the Polish Constitutional Tribunal argues that judges tend to assume partisan positions especially in strongly politicized (and, as a consequence, mediatized) cases. Constitutional conflict issues, in which usually both parties are political actors, fit this pattern. Accordingly, the argument goes, if judicial decision-making is perceived as a collegial game, dissents are discouraged. This is an explanation for the low number of dissenting opinions in the general case-law. If collegial constraints are less binding, e.g., one of the judges decided to make their disagreement public, the default logic will be partisanship. ${ }^{35}$ However, the Polish and Romanian particularities do not necessarily characterize all constitutional forums of the region. In the case of the Czech Constitutional Court, for instance, researches demonstrate a reduced influence of politics on the court's decisions. This is attributed to the politically less conditioned practice of appointing constitutional court judges (comparative to other countries of the region), high political fragmentation (which is extremely interesting compared to Romania, where high political fragmentation arguably contributed to an enhanced polarization of the Court), and policy fragmentation. ${ }^{36} \mathrm{~A}$ fourth trend model of

${ }^{34}$ It is also debatable, whether constantly reoccuring dissents by the same judge or coalition of judges should rather be considered a sign of disintegration, than of polarization. [see Lembcke (2007)]

35 Wołek, Artur and Kender-Jeziorska (2019) 155-83.

36 Šipulová (2019) 155-83. 
dissenting behavior is presented by the judges of the Hungarian Constitutional Court. In this case, the general perception was that prior to 2010, before the leading Hungarian political force, FIDESZ, has ensured a continuous $2 / 3$ majority in the legislature, Constitutional Court decisions were not influenced by judges' former political affiliation. This is especially true with respect to the early years of the court, marked by the presidency of Judge Sólyom. However, a recent study found that partisan behavior can be demonstrated prior to 2010 in the case of leftist judges, while rightist judges apparently were less willing to form coalitions. ${ }^{37}$ Unfortunately, since 2013, when the Court's competences were curtailed and its' composition changed (loyal, right-wing judges becoming a majority), the Court mostly lost its relevance. This is an inverse trend to the Romanian Court, where politician-judges are gradually disappearing from the bench, while in Hungary former MP's are more likely to become constitutional judges since 2010 .

\subsection{Remedies}

The Court's possibilities to offer concrete remedies are limited by the constitutional design, which establishes that decisions can be taken solely 'ex nunc'. Moreover, the Court has to face also the distrust of the other branches, especially of the legislative and the judiciary, which both perceived it as an undemocratic (counter-majoritarian), respectively as an unprofessional (former MP's outnumbering recognized scholars and magistrates) body that limits their authority. ${ }^{38}$ In practice, this resulted in real difficulties for the Court in enforcing its decisions, which led to the introduction of lengthy paragraphs in the decisions' texts, through which the Court attempted to emphasize the mandatory character of its' decisions, concerning both the ruling and the reasoning parts (with references to the constitutional texts and its' own case-law).

Accordingly, the Court, in its' initial approach to constitutional conflict cases, refrained from offering concrete remedies and opted to formulate general rules of conduct for the parties, such as:

[...] the President of Romania does not enjoy a right to veto, but might ask the primeminister to withdraw his proposal in cases when the designated person does not fulfill the necessary legal conditions to become a member of the Executive. ${ }^{39}$

The Court maintained this practice for 6 years, with a single, rather particular exception. ${ }^{40}$ Later on, however, it started to abandon this cautious approach and offer concrete remedies, using a noticeably more imperative language:

37 Pócza et al. (2019) 155-83.

38 This profound distrust explains why initially the Constitution preserved a right to veto for the Parliament, which could override ex ante review decisions of the Court with a qualified majority vote. Although never used in practice, this provision has been eliminated at the 2003 revision of the fundamental law.

39 Decision no. $356 / 2007$.

40 Decision no. 1222/2008. However, here, rather uncharacteristically, the ruling resembles more an appellate decision than a constitutional one, the Court finding that a High Court of Cassation and Justice decision is not enforceable against the President of Romania, because he was not part of the proceedings. 
The Senate of Romania will decide whether to terminate or not Mr. Mora Akos Daniel's mandate of senator, after the legal interpretation of art.25 para. (2) of Law no. $176 / 2010 .{ }^{41}$

It has not been a regular practice of the Court to offer concrete remedies in collision of competence cases. Remedies have only started to occur regularly since 2013, a decade after the introduction of this type of jurisdiction and the first decisions with similarly imperative ruling has been issued in 2015. ${ }^{42}$ At that stage there was no consensus amongst theorists about the Court's competence to issue concrete remedies. Some argued that while it shall indicate the conduct to which authorities should comply it cannot compel authorities to exercise their constitutional powers. ${ }^{43}$

Therefore, the first distinction has to be made between 'general rules' and 'remedies', where the first is a general recommendation about the preferable conduct that should be assumed by the parties, while the second is a more direct indication about a concrete action or abstention.

Even, if the Court considers that the reasoning and the ruling of its decisions are equally binding, there is an arguable difference in weight between a remedy phrased in the reasoning and one inserted in the ruling. The second distinction thus is made according whether the remedy is placed in the reasoning or in the ruling part of the decision.

On the basis of the above distinctions, it can be observed that in the earlier, more cautious years, the Court preferred to formulate 'general rules' of conduct, inserted either into the reasoning or the ruling part of the decisions. The Court moved to regularly issuing 'remedies' from 2012, and since than 'general rules' only occur in the reasoning of the decisions. (fig.5)

This rate of remedies is significantly larger than the one characterizing the entire caselaw of the Court, where only approximately $5 \%$ of the rulings offer remedies ${ }^{44}$

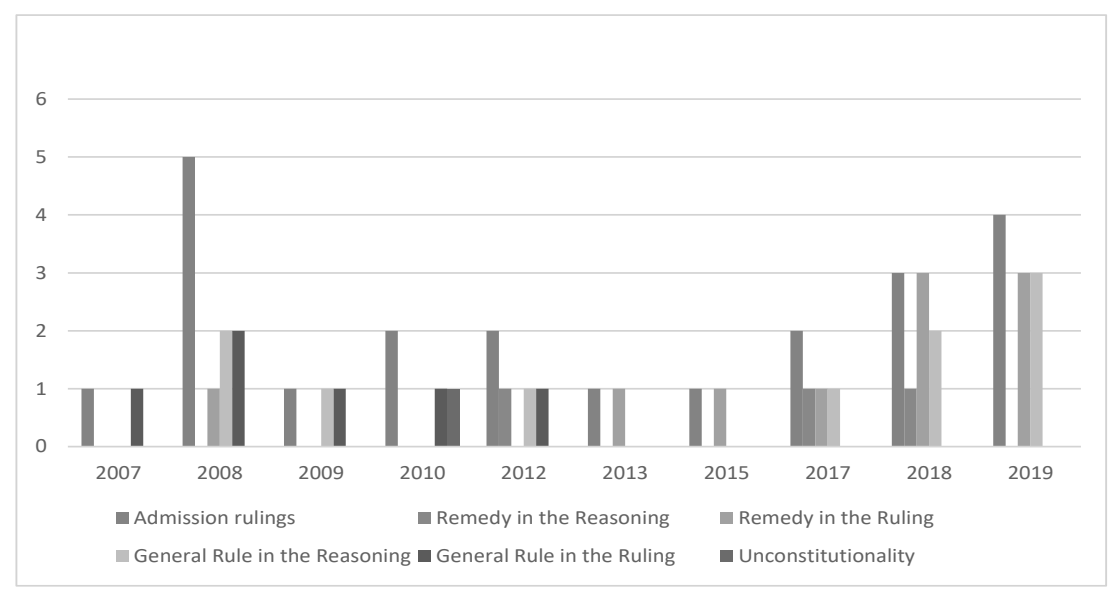

Figure 5. Remedies

${ }^{41}$ Decision no. 460/2013.

42 'The Senate has the obligation to issue its decision [...] in writing [...] to forward it to the competent public authorities and to publish it in the Official Gazette' Decision no. 261/2015.

43 Gârleșteanu (2012) 41-51.

${ }^{44}$ Kuti (2019) 155-83. 
The wording of the Court's decisions apparently do not offer a theoretical explanation for this shift in attitude regarding remedies so contextual factors must be taken into consideration.

From this perspective, it can be observed that in periods of lower general political stability ${ }^{45}$ the number of constitutional conflict decisions increased, that the Court is more clearly polarized in such decisions, and that this type of decisions generate the highest number of dissenting opinions.

\section{CONCLUSIONS}

At the outset, the Romanian Constitutional Court attempted to avoid to become an arbitrator in constitutional conflict issues, arguably due to the significant political connotations of such cases. The Court was highly cautious in identifying the theoretical grounds and the scope of its review power over constitutional conflicts, and for several years avoided to offer concrete remedies, preferring to point to general rules of conduct to be followed by the authorities in conflict.

However, as the general political context became more unstable, misusing of institutions to gain or consolidate advantages over political opponents became more frequent. In the realm of constitutional adjudication, this meant that the traditional, unwritten convention on the appointment of judges has been dropped and political actors tried use the Court as means for settling political disputes. Consequently, the Court's approach to constitutional conflict cases has changed. Arguably, the Court's latest decisions, especially those involving collisions of competence between the executive and the president of the republic, might be considered as an incipient tendency to shift from semi-presidential towards parliamentary republic.

Unlike in the case of its' general case-law, in constitutional conflict issues the judges are demonstrably polarized along political lines: an analysis of dissenting behaviors reveal that networks were formed along political affiliations, however, since career magistrates have outnumbered politician-judges (even if at this stage it is too close to call), there are signs that the former might form a new, distinct pole.

It is also puzzling, that there are clear differences in the admission record of claims, depending on which authority has lodged them. Here, the executive seems to be the strongest player as if, apparently, the Court's decisions would somehow attempt to compensate for the instability of cabinets. On the other hand, the past decade's Romanian anti-corruption campaign was also attempted to be used by political actors for account settling, could also be a reason for the relatively week success rate of constitutional conflict claims lodged on behalf of the judicial power.

The Court has shifted from its initial stance and arguably became a stronger player in settling constitutional conflicts. Losing its cautiousness, it has shifted from general recommendations to concrete remedies, a shift which is also nicely portrayed by the changes in the language of the decisions. The 'will immediately' phrase repeatedly occurs in the later decisions' rulings, already not recommending but dictating the desirable conduct.

45 Indicators of 'low general political stability': President and parliamentary majority coming from different parties/coalitions; unstable executives: 6 different prime ministers and 9 different cabinets in the 2012-2018 period; unstable governing coalitions: 6 different coalitions succeeded in the same period, while there were only 2 parliamentary elections; President had to face an impeachment procedure (2012) 
Examples from other constitutional forums of the region show, highly politicized and mediatized cases - such as constitutional conflicts - are more likely to produce disagreement between the judges (often expressed through dissenting opinions) and polarization of the court based on ideological or political convictions. Albeit, as the Czech example shows, if appropriate conditions are ensured, judges apparently might be able to ignore inner political convictions (or external pressures) even in politically highly sensitive cases.

Constitutional Courts are by design different (and separate) from ordinary courts, so as to make them more lenient to politics and to enable them to decide conflicts that courts of justice could not qualify as a legal dispute. Constitutional conflicts are ultimately about the distribution and limits of constitutional power and relate to the rule of law. In a recent decision, Kövesi v. Romania, ${ }^{46}$ the European Court of Human Rights found that the dismissal of the applicant from office (as chief prosecutor of the National Anticorruption Directorate) by a Presidential decree signed under the order of the Constitutional Court, ${ }^{47}$ violated her rights under article 6 and article 10 of the European Convention of Human Rights. The procedure of dismissal that was found in contradiction with article 6 of the Convention, has been warranted by the Romanian Constitutional Court as being in terms with the requirements of the Constitution. The Constitutional Court's decision was published with three dissenting opinions (two by career magistrates, one by a politicianjudge), none of them touched upon the issue of fair trial: Apparently while debating over the form, constitutional judges lost sight of the substance.

\section{REFERENCES}

Benke, K. n.d. 'Provocări ale controlului de constituţionalitate: trecut și viitor'. (Challenges for the Control of Constitutionality: Past and Future) <https://www.yumpu.com/ro/document/ $\mathrm{read} / 24528572 /$ provocari-ale-controlului-de-constitutionalitate-> accessed 18 November 2019.

Blokker, P., 2012. 'Romanian Constitutionalism: Form Without Content?' https://papers.ssrn.com/ sol3/papers.cfm?abstract_id=2146568. accessed 20 November 2019.

Deleanu, I., Institutii si procedure constitutionale [Constitutional institutions and proceedings] (C.H. Beck 2006.) 865.

Gârleșteanu, L. G., 'Conflictele juridice de natură constituțională dintre autoritățile publice' (The Legal Conflicts of Constitutional Nature between Public Authorities) Revista Transilvană de Ştiințe Administrative. 1(30) (2012) pp. 41-51.

Iancu, B., 'Constitutionalism in Perpetual Transition: The Case of Romania.' in Iancu, B. (ed) The Law/Politics Distinction in Contemporary Public Law Adjudication, (Eleven International Publishing 2011) 187-211.

Kuti, Cs. 'The Romanian Constitutional Court: Muddling through democratic transition.' in Pócza, K. (ed) Constitutional Politics and the Judiciary. Decision-making in Central and Eastern Europe, edited by Pócza, K., (Routledge 2019) 155-83.

Lembcke, O. W., 'Hüter de Verfassung: Eine institutionentheoretische Studie zur Autorität des Bundesverfassungsgericths' (2007) 379. Tübingen: Mohr Siebeck.

Mungiu-Pippidi, A., 'Interview with President of the Romanian Constitutional Court, Ion Muraru.' (1997) East European Constitutional Review 6 (1): 78-83.

Perju, V., 'A sosit timpul pentru reformarea Curtii Constitutionale?' [Has the Time Come for Reforming of the Constitutional Court?] Contributors.ro, (2010. November 29.) http://www. contributors.ro/idei-si-solutii/a-sosit-timpul-pentru-reformarea-curtii-constitutionale-partea-i accessed 28 November 2019.

46 Kövesi v. Romania, no.3594/19, 05. May 2020.

47 Decision no.358/2018. 
Šipulová, K., 'The Czech Constitutional Court: Far away from political influence' in Pócza, K. (ed) Constitutional Politics and the Judiciary. Decision-making in Central and Eastern Europe, (Routledge 2019) 155-83.

Tănăsescu, S., 'Constitutional Review of Judicial Activism?' (2013) 2 International Journal of Law and Jurisprudence Law Review 19-36.

Weber, R., 'The Romanian Constitutional Court: In Search of its Own Identity' in Wojciech Sadurski (ed) Constitutional Justice, East and West. Democratic Legitimacy and Constitutional Courts in Post-Communist Europe in a Comparative Perspective (Kluwer Law International 2002).

Wołek, A. and Kender-Jeziorska, I., 'The Polish Constitutional Tribunal: Defence beyond the veil of activism' in Pócza, K. (ed) Constitutional Politics and the Judiciary. Decision-making in Central and Eastern Europe (Routledge 2019) 155-83. 